\title{
FACTORS THAT INFLUENCE THE PASSAGE OF ASCORBIC ACID FROM SERUM TO CELLS IN HUMAN BLOOD
}

\author{
By MARTIN HEINEMANN ${ }^{1}$ AND PAULINE M. HALD \\ (From the Department of Internal Medicine, Yale University School of Medicine, New Haven)
}

(Received for publication January 16, 1940)

Previous work has demonstrated that ascorbic acid, which has been added to defibrinated blood, is taken up by the cells (1). The advantages offered by the method of Mindlin and Butler (2) have made it possible to investigate the factors which influence the passage of ascorbic acid into the cells. This paper deals with the effect of time, temperature and oxygen.

\section{METHODS}

Ascorbic acid in serum was determined by the method of Mindlin and Butler (2) with the following modifications.

(1) Neither potassium oxalate nor potassium cyanide was used. An anticoagulant was not necessary because the blood was defibrinated by stirring with a glass rod. The possible erroneous influence of added $\mathrm{KCN}$ has been demonstrated by other observers $(3,4,5)$, as well as in this laboratory. Furthermore, addition of oxalate, cyanide or any other salt seemed undesirable, since changes in cell volume had to be avoided.

(2) The strength of the metaphosphoric acid solution is of great significance for the reliability of the colorimetric method. With ascorbic acid a stable color develops; other reducing substances cause progressive fading of the indicator. Mindlin and Butler pointed out, and our own observations agree that, with solutions of pure ascorbic acid, the stability of the reduction of the dye depends on the $\mathrm{pH}$ of the final mixture of equal volumes of buffered dye and metaphosphoric acid. The dye solution invariably gave the desired $\mathrm{pH}$ of 7.0 when made according to the directions given by the aforementioned authors. Metaphosphoric acid solutions, however, made up by weight from three different brands, varied widely in strength and were all weaker than theory demanded. Since it is known that metaphosphoric acid is partially converted to the ortho form on standing, the strength of a solution can be adjusted only by standardization. The metaphosphoric acid was, therefore, titrated with $0.1 \mathrm{~N}$ sodium hydroxide, using phenolphthalein as an indicator. In agreement with the observations of Mindlin and Butler, stable blanks were obtained when the final $\mathrm{pH}$ of the dye-metaphosphoric acid mixture was kept at 4.2 to 4.3. This resulted with solutions of the acid which were 0.21 to $0.22 \mathrm{~N}$. The same normality was attained in

1 This work was aided by a grant from the Markle Foundation. filtrates from serum when the deproteinization had been carried out with a solution of this acid 0.51 and $0.52 \mathrm{~N}$.

(3) Procedure. In most of the experiments large amounts of ascorbic acid were added to the blood. Smaller aliquots of serum were therefore necessary. In control experiments identical results were obtained on filtrates derived from $0.5 \mathrm{cc}$., 1 ; cc. or $2 \mathrm{cc}$. of serum, provided proportional volumes of distilled water and metaphosphoric acid were used in the precipitation. When $0.5 \mathrm{cc}$. was used the precipitate was thrown down by centrifuging to insure $1 \mathrm{cc}$. of filtrate for analysis. This was then diluted to $6 \mathrm{cc}$. with $0.21 \mathrm{~N}$ metaphosphoric acid. Four cc. of this diluted filtrate added to an equal volume of the buffered dye solution were used for the colorimetric reading. ${ }^{2}$

Determinations of ascorbic acid on filtrates made from ten $0.5 \mathrm{cc}$. aliquots of the same serum gave results which varied by not more than 2 per cent.

(4) Calculation. Repeated series of known amounts of ascorbic acid in metaphosphoric acid solution ( 0.21 to $0.22 \mathrm{~N}$ ) were read in the photoelectric colorimeter. The concentrations of ascorbic acid ranged from 0.4 to 2.4 mgm. per cent. The constant, $K$, used in the equation $C=K\left(\log G_{8}-\log G_{b}\right)$ was found to vary between 1.010 and 1.108 , averaging $1.059 \pm 0.049$. The stability of this constant was not studied further, since in this investigation comparative and not absolute measurements of ascorbic acid were contemplated.

Ascorbic acid in whole blood was determined by the method of Emmerie and van Eekelen (6), as previously described (1). In a few instances, for purposes of comparison, ascorbic acid in serum was also measured by this method.

Blood cell volumes were measured by the hematocrit method described by Eisenman, Mackenzie and Peters (7).

\section{EXPERIMENTAL RESULTS}

Crystalline ascorbic acid was added to human blood which had been defibrinated with a glass rod. In order to avoid hemolysis and changes of cell volume, it was not introduced directly into the whole blood but was first dissolved in a portion of the serum. (It was demonstrated by innumerable controls that the cell volume was not al-

2 Although the Evelyn colorimeter in use in this laboratory has no $8 \mathrm{cc}$. aperture, it was found that satisfactory readings were obtained when the $10 \mathrm{cc}$. aperture was used. 
tered by any of the experimental procedures employed in this investigation.) The defibrinated blood was then divided into two parts. From one the serum was separated at once and analyzed for ascorbic acid. The remainder of the serum, which will be spoken. of as "separated serum," and the remaining portion of whole blood were then placed in stoppered Erlenmeyer flasks and kept at the same temperature. Samples of the blood, removed at intervals, were centrifuged, and the sera thus secured were analyzed for ascorbic acid. These sera will be referred to as "true serum"that is, serum which has been in contact with the blood cells up to the moment of analysis. Portions of the separated serum were analyzed at the same intervals. This permitted a comparison of the behavior of serum with and without contact with the blood cells.

Ten studies were conducted at refrigerator temperature (approximately $7^{\circ}$ ) under atmospheres of both air and nitrogen, with and without shak-

TABLE I

\begin{tabular}{|c|c|c|c|}
\hline $\begin{array}{l}\text { Experiment } \\
\text { number }\end{array}$ & $\underset{\text { incubation }}{\text { Time of }}$ & \multicolumn{2}{|c|}{$\begin{array}{c}\text { Ascorbic acid in whole } \\
\text { blood }\end{array}$} \\
\hline 1 & $\begin{array}{r}\text { minutes } \\
0 \\
195 \\
285\end{array}$ & \multicolumn{2}{|c|}{$\begin{array}{l}\text { mgm. per liter } \\
\text { Air } \\
240.6 \\
243.7 \\
240.6\end{array}$} \\
\hline 2 & $\begin{array}{r}0 \\
255 \\
375 \\
480\end{array}$ & $\begin{array}{l}219.0 \\
219.0 \\
215.3 \\
220.5\end{array}$ & \\
\hline 3 & $\begin{array}{r}30 \\
180 \\
360 \\
540\end{array}$ & $\begin{array}{l}47.5 \\
47.5 \\
46.0 \\
42.5\end{array}$ & \\
\hline . 4 & $\begin{array}{r}30 \\
180 \\
360 \\
540\end{array}$ & $\begin{array}{l}48.8 \\
46.3 \\
42.5 \\
40.0\end{array}$ & \\
\hline 5 & $\begin{array}{r}30 \\
540\end{array}$ & $\begin{array}{l}58.3 \\
47.2\end{array}$ & \\
\hline 6 & $\begin{array}{r}0 \\
255\end{array}$ & $\begin{array}{l}63.9 \\
44.4\end{array}$ & $\begin{array}{c}\text { Nitrogen } \\
63.9\end{array}$ \\
\hline 7 & $\begin{array}{r}0 \\
255\end{array}$ & $\begin{array}{l}68.8 \\
50.0\end{array}$ & 69.9 \\
\hline
\end{tabular}

Experiments numbers 1 and 2 at approximately $23^{\circ} \mathrm{C}$.; numbers 3,4 and 5 at $37^{\circ} \mathrm{C}$.; numbers 6 and 7 at $37^{\circ} \mathrm{C}$.; while continuously shaken. ing, duplicating in every respect except temperature the experiments to be described below. In none was any decrease of ascorbic acid concentration detected in either true or separated serum.

It has already been shown and new evidence is presented that, when whole blood is allowed to stand at room temperature in contact with air, no loss of ascorbic acid can be demonstrated, even after several hours (1). When blood was kept at $37^{\circ} \mathrm{C}$., slight losses occurred. Appreciable losses, however, were observed at this temperature when the blood was agitated continuously. It was found that if the blood was kept under an atmosphere of nitrogen these losses were entirely prevented. Observations on the stability of ascorbic acid added to defibrinated blood under these various conditions are shown in Table I.

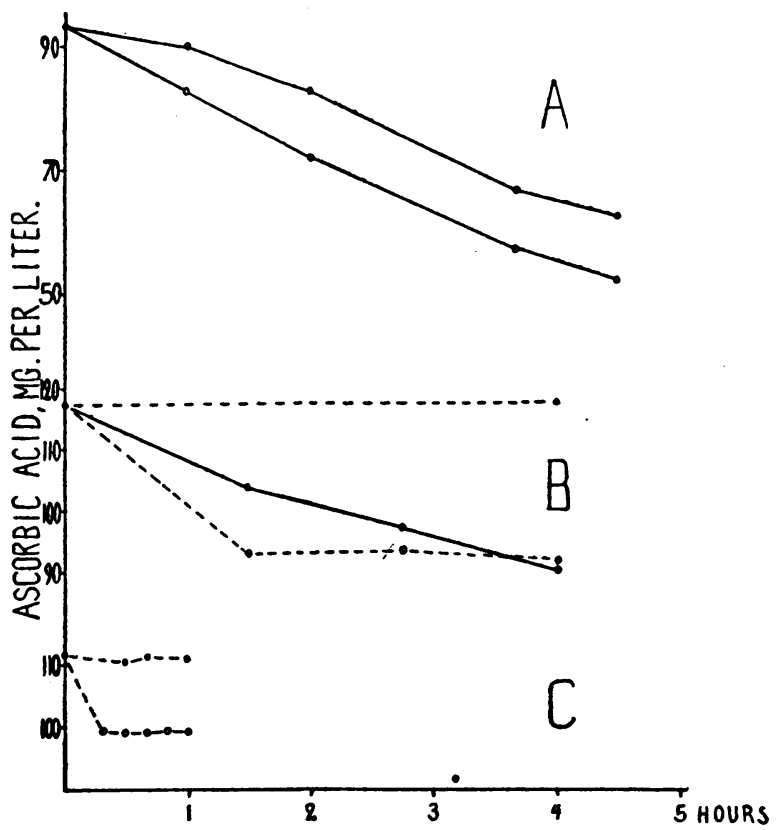

Fig. 1. Conditions Influencing the Concentration of Ascorbic Actd in "Separated" and "True Serum" AT $37^{\circ} \mathrm{C}$.

Ascorbic acid added at zero time. Solid circles represent separated serum, open circles true serum; solid lines indicate that the blood was allowed to 'stand without motion, broken lines that it was continually agitated. $A$ under air, $B$ and $C$ under nitrogen.

Figure $1 A$ depicts the results of one typical experiment out of 14 that agreed in all respects. Blood and serum were kept exposed to air at $37^{\circ} \mathrm{C}$. It was consistently found that both the 
separated and the true serum lost ascorbic acid progressively, but that the loss from the separated serum was always less than that from the true serum. To determine if these losses could be due to conversion of ascorbic acid to the reversibly oxidized form which cannot be detected by the method applied, simultaneous analyses were made employing $\mathrm{H}_{2} \mathrm{~S}$ according to the method of Emmerie and van Eekelen. From these comparisons it appeared that the losses in both separated and true sera were real ones. Experiments number 3,4 , and 5 of Table I show that ascorbic acid is protected in whole blood to some extent. The losses observed in whole blood during the first 3 hours can in no way account for the far greater decrease in ascorbic acid concentration taking place in true serum during the same period. These experiments, therefore, indicate that ascorbic acid has entered the cells. Neither by extending these experiments over periods as long as 9 hours nor by determining the ascorbic acid content in both sera at intervals as short as 15 minutes was any additional information obtained.

TABLE II

Effect of nitrogen on the stability of ascorbic acid in serum at $37^{\circ} \mathrm{C}$.

\begin{tabular}{|c|c|c|c|}
\hline $\begin{array}{c}\text { Experiment } \\
\text { number }\end{array}$ & $\underset{\text { incubation }}{\text { Time of }}$ & $\begin{array}{c}\text { Separated } \\
\text { serum }\end{array}$ & $\begin{array}{c}\text { True } \\
\text { serum }\end{array}$ \\
\hline 1 & $\begin{array}{c}\text { minutes } \\
0 \\
240\end{array}$ & $\begin{array}{c}\text { mgm. per liter } \\
108.5 \\
106.5\end{array}$ & $\begin{array}{c}\text { mgm. per liter } \\
79.0\end{array}$ \\
\hline 2 & $\begin{array}{r}0 \\
240\end{array}$ & $\begin{array}{l}117.0 \\
114.5\end{array}$ & 75.5 \\
\hline 3 & $\begin{array}{r}0 \\
90 \\
135 \\
180 \\
240\end{array}$ & $\begin{array}{r}100.5 \\
98.0\end{array}$ & $\begin{array}{l}84.0 \\
70.0 \\
68.0 \\
66.0\end{array}$ \\
\hline
\end{tabular}

The protection against loss of ascorbic acid by an atmosphere of nitrogen, shown before for whole blood, was also observed in solutions of pure ascorbic acid in 1 per cent trichloroacetic acid, which deteriorate rapidly in air. From the data presented in Table II and in Figure $1 B$ and $C$, it is evident that ascorbic acid in separated serum is also protected.

While there is no appreciable loss of ascorbic acid from separated serum, the concentration of ascorbic acid in true serum decreases even in an atmosphere of nitrogen.

The effect of an atmosphere of nitrogen on the experimental results is twofold: (1) it stabilizes ascorbic acid in separated serum, (2) the decrease in ascorbic acid concentration in true serum, which was progressive under air, is self-terminative.

The rate of entrance of ascorbic acid into the blood cells, irregular in the observations thus far presented, was considerably enhanced by continuously shaking the blood. This agitation was effected in the incubator by placing the flasks on a rack oscillated so gently by a windshield wiper motor that the cells were never mechanically damaged. In order to avoid temperature changes, ${ }^{8}$ which were found to cause fluctuations in the curves in the beginning of this investigation, the nitrogen was led into the incubator and was washed by passing through a bottle of distilled water. From this wash bottle the gas was conducted through a manifold to a series of smaller wash bottles, each of which was directly connected with a $25 \mathrm{cc}$. Erlenmeyer flask containing $2 \mathrm{cc}$. of blood or serum. By means of control screws the pressure of nitrogen reaching the surface of the fluid in each flask could be kept approximately equal. During the first 15 minutes the pressure was kept relatively high. It was then partially reduced for the remainder of the experiment.

In Figure $1, B$ and $C$, is presented evidence of the influence of shaking on the rate of disappearance of ascorbic acid from true serum. Figure 1, $C$, representative of 5 such experiments, shows that the passage of ascorbic acid into the cells is self-terminative, ceasing within 30 minutes.

\section{DISCUSSION}

At $37^{\circ} \mathrm{C}$., in all the experiments presented, the concentration of ascorbic acid, added to whole blood, decreases in serum which is kept in contact with cells (true serum). These losses in true serum are not due to reversible oxidation but must be attributed to passage of ascorbic acid from the serum to the cells. This entrance of ascorbic acid

\footnotetext{
3 These temperature changes possibly indicate the cause for unexplainable fluctuations observed in previous work (1, p. 757) where temperature equilibrium was not rigidly controlled.
} 
into the blood cells occurs also in an atmosphere of nitrogen, in which deterioration of ascorbic acid is prevented in whole blood as well as in separated serum, at $37^{\circ} \mathrm{C}$., even when the blood is continuously shaken.

The fact that the transfer of ascorbic acid, established at $37^{\circ} \mathrm{C}$., is entirely prevented at $7^{\circ} \mathrm{C}$., whether the blood is exposed to air or nitrogen, suggests its association with some metabolic activity or chemical reaction rather than simple diffusion. In this respect it is analogous to the transfers of phosphate which were investigated by Halpern (8).

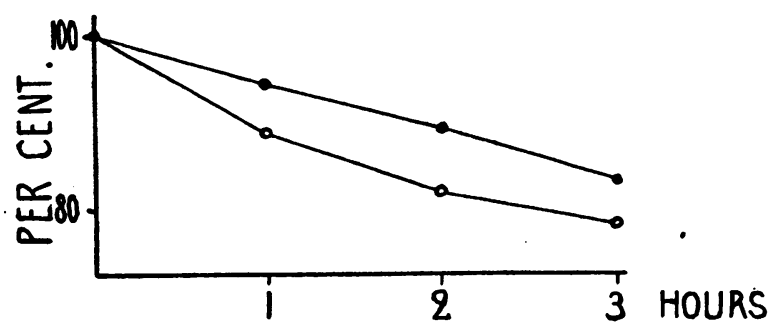

Fig. 2. Concentration of Ascorbic Acid in "Separated" and "True Sera"

The curves represent the average of 14 experiments at $37^{\circ} \mathrm{C}$. under air, expressed as per cent of the amount present immediately after addition of ascorbic acid at zero time. $\longrightarrow$ represents separated serum, $\mathrm{O} \longrightarrow \mathrm{O}$ true serum.

Whether the rate of transfer and the amounts exchanged are different under air and nitrogen is as yet undecided. In Figure 2 the trends of the curves representing separated and true sera kept under air show that the rate of deterioration in the former is almost linear; in true serum, however, the ascorbic acid concentrations decline faster than in separated serum during the first hour of the experiment. Subsequently, the two curves run more or less parallel. From this observation it seems that, under air, in addition to the amounts which enter the cells, a portion of the ascorbic acid is destroyed. The destructive process appears to be continuous, while the transfer is selfterminative just as it is under anaerobic conditions. The deterioration and the transfer of ascorbic acid are both accelerated by continuous shaking; in one typical experiment after only 45 minutes the concentration in true serum decreased from 106.0 mgm. per liter at zero time to $83.0 \mathrm{mgm}$. per liter, and that in separated serum to $90.0 \mathrm{mgm}$. per liter; the corresponding data for sera kept under nitrogen were $94.0 \mathrm{mgm}$. per liter and $106.5 \mathrm{mgm}$. per liter.

The experiments under air leave no doubt that ascorbic acid enters the blood cells. In the 5 experiments under nitrogen, of which Figure $1, C$, is typical, and in which the concentrations of ascorbic acid in serum were raised to between 100 and 120 mgm. per liter, the decrease in true serum varied from 11.3 to 19.2 per cent of the initial concentration. In 3 of these experiments, for which blood of the same person was used, the decrease varied from 11.3 to 12.1 per cent. Quantitative deductions as to absolute amounts require more data than are at present available. In two instances where different amounts of ascorbic acid were added to samples of the same blood, the absolute amounts taken up by the cells diminished as serum concentrations decreased. Estimations of the concentrations of ascorbic acid per unit of water in serum and cells indicated that at high concentrations the distribution ratios (calculated as $\frac{\text { Ascorbic acid of serum }}{\text { Ascorbic acid of cells }}$ ) were greater than unity, approaching unity at lower concentrations-i.e., about $35 \mathrm{mgm}$. per liter of water.

\section{SUMMARY AND CONCLUSIONS}

1. After addition of ascorbic acid to defibrinated human blood, its concentrations were followed in serum separated at once and in serum left in contact with cells.

2. At $37^{\circ} \mathrm{C}$., ascorbic acid enters the blood cells.

3. This transfer is self-terminative and occurs under an atmosphere of air as well as of nitrogen, the latter preventing deterioration of ascorbic acid in serum and in whole blood.

4. The passage of ascorbic acid into the cells appears to be associated with some metabolic activity since it was never observed at lower temperatures.

5. The rate of transfer of ascorbic acid is enhanced by avoiding sedimentation of the blood.

\section{BIBLIOGRAPHY}

1. Heinemann, M., The distribution of ascorbic acid between cells and serum in relation to its urinary excretion. J. Clin. Invest., 1938, 17, 751.

2. Mindlin, R. L., and Butler, A. M., The determination of ascorbic acid in plasma; a macromethod and micromethod. J. Biol. Chem., 1938, 122, 673. 
3. Friedman, G. J., Rubin, S. H., and Kees, W., Effect of addition of $\mathrm{KCN}$ to whole blood on indophenolreducing power of plasma. Proc. Soc. Exp. Biol. and Med., 1938, 38, 358.

4. Farmer, C. J., and Abt, A. F., Invalidation of plasma ascorbic (cevitamic) acid values by use of potassium-cyanide. Proc. Soc. Exp. Biol. and Med., 1938, 38, 399.

5. Cushman, M., and Butler, A. M., Use of cyanide in the determination of ascorbic acid. Proc. Soc. Exp. Biol. and Med., 1938, 39, 534.
6. Emmerie, A., and van Eekelen, M., The chemical determination of vitamin $\mathrm{C}$ with removal of interfering reducing and coloured substances. Biochem. J., 1934, 28, 1153.

7. Eisenman, A. J., Mackenzie, L. B., and Peters, J. P., Protein and water of serum and cells of human blood, with a note on the measurement of red blood cell volumes. J. Biol. Chem., 1936, 116, 33.

8. Halpern, L., The transfer of inorganic phosphorus across the red blood cell membrane. J. Biol. Chem., 1936, 114, 747. 